\title{
Development of parotitis after radioiodine therapy in a differentiated thyroid cancer patient: Case report
}

\section{Diferansiye tiroid kanser hastasında radyoiyot te- davisi sonrası parotit gelişimi: Olgu sunumu}

*Zekiye Has bek, **Kasım Durmuş, ***Aynur Engin, **Emine Elif Altuntaş

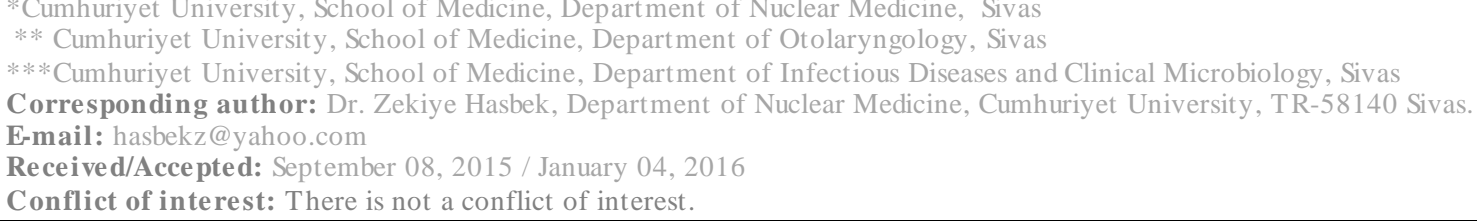

\section{SUMMARY}

In this article, we report a 51 years old female patient treated with radioactive iodine (RAI- $\left.{ }^{131} \mathrm{I}\right)$ treatment for thyroid papillary carcinoma and developing parotitis on the 24 hour following treatment. Siaload enitis after high dose ablative therapy with ${ }^{131} \mathrm{I}$ is a relatively common complication with a low clinical impression. Taste alteration or loss, and nausea and vomiting due to radiation sickness are the other most frequent side effects. Xerostomia is an important problem increasing morbidity of the patients. For this reason, it is important to prevent xerostamia by following serum amylase levels in symptomatic patients. By taking into account that not only bacterial and viral factors but also radiation may cause sialoadenitis, one has to rule out other parotisis possibilities by clinical and laboratory findings before claiming that salivary gland enlargement developing after radioiodine is a complication of radiation. Moreover, history of RAI treatment should be given importance in patients applying either to emergency services or to Ear Nose Throat and Infectious Diseases Department with dry mouth.

Keywords: Radioiodine therapy, differentiated thyroid carcinoma, parotitis

\section{ÖZET}

Bu makalede, diferansiye tiroid papiller karsinom nedeniyle radyoaktif iyot (RAI- ${ }^{131}$ I) tedavisi verilen ve tedavinin 24. saatinde parotitis gelişen 51 yaşındaki kadın hastayı sunduk. ${ }^{131}$ I ile yüksek doz ablasyon tedavi sonrası siyaloadenit, düşük klinik izlem ile birlikte rölatif olarak sık bir komplikasyondur. Radyasyon hastalığ1 nedeniyle tat alma bozukluğu veya kaybı, ve bulantı ve kusma diğer en sik yan etkilerdir. Kserostomi hastaların morbiditesini artıran önemli bir problemdir. Bu nedenle, semptomatik hastalarda serum amilaz düzeylerinin takibi, kserostominin önlenmesi için önemlidir. Bakteriyel ve viral etkenler dişında radyasyonun da sialadenit yapabileceği dikkate alınarak, radyoaktif iyot sonrası gelişen tükürük bezi büyümesinin, radyasyon komplikasyonu olduğunu söylemeden önce, klinik ve laboratuvar bulgularla birlikte diğer parotit olasıllklarının da ekarte edilmesi gereklidir. Bunun yanısıra, gerek acil servislerde gerekse Kulak Burun Boğaz (KBB) departmanlarında ağı kuruluğu ile başvuran hastalarda, hikayede mutlaka RAI tedavi öyküsünün de sorgulanması önemlidir.

Anahtar sözcükler: Radyoiyot tedavi, diferansiye tiroid karsinom, parotit 


\section{INTRODUCTION}

Radioiodine $\left({ }^{131} \mathrm{I}\right)$ concentrates in thy-roid cells and it can destroy thyroid cells. So, in differentiated thyroid can-cer patients, radioiodine therapy can be used to destroy any thyroid tissue not removed by surgery or to treat spread to lymph nodes and other parts of the body [1]. For an effective RAI theraphy, thyroid-stimulating hormone (TSH) levels of the patients should be high. TSH stimulates thyroid tissue (and cancer cells) to take up radioactive iodine. Serious acute complications are extremely rare during RAI therapy. However, some early complications can be seen. Shortterm side effects of RAI treatment may include neck tenderness and swelling, nausea and vomiting due to radiation sickness, swelling and ten-derness of the salivary glands, dry mouth, and taste alteration.

Following RAI administration, ensuring hydration, drinking lemon juice, suck-ing lemon candies, treating constipation with laxatives, and using antiemetics help both remission of symptoms and decrease the exposure of bladder, sali-vary glands and colon to radioactivity. We present a case where the patient developed radiation sialadenitis after radiactive iodide therapy for thyroid papillary cancer that resulted in a high level of serum amylase and severe parotid swelling.

\section{CASE REPORT}

A 51 years old female patient undergoing total thyroidectomy for thyroid papillary carcinoma was re-ferred to the Nuclear Medicine Department of Cumhuriyet University for radioactive iodine (RAI) treatment with 131I. In her neck ultrasonography before ablation therapy with RAI, a few lymph nodes were observed in both cervical chains. Moroever, a thrombosed appearance originating from the left ex-ternal carotid artery of the left thyroid gland with a blind ending at the thyroid gland, and a thrombosed appearance of the superior thryoid artery with min-imal arterial flow at the lumen area were observed. There was no hypere-mia, edema or heat increase in the pa-rotid region before starting the treat-ment.

Her thorax X-ray was normal. Thyroid scintigraphy performed with Tc99m pertechnetate before ablation revealed a miminal residual thyroid tissue uptake at the left lobe of the thyroid gland. During her hospitalization, thy- roid function tests revealed: $\mathrm{fT} 3: 1.52 \mathrm{pg} / \mathrm{mL}$, fT4: $0.23 \mathrm{ng} / \mathrm{dL}$, TSH: $96.93 \mu \mathrm{IU} / \mathrm{mL}$, Antithyroglobulin antibody (Anti-Tg Ab): 0.001 $\mathrm{IU} / \mathrm{mL}$, thy-roglobulin $(\mathrm{Tg}): 0.51 \mathrm{ng} / \mathrm{mL}$. Following oral administration of $100 \mathrm{mCi}$ I-131 capsule, the patient was isolated in an iodine room. The patient was recom-mended to drink plenty of water, suck candy and eat lemon. Twenty four hours after the RAI therapy, the patient was found to have a bilateral parotid hardening and swelling. The patient had no additional symptoms such as pain, fever, etc. Her history was re-examined.

It was learned that the patient had a complaint of dry mouth after total thyroidectomy. The patient had no history of tumor or medications affect-ing salivary glands such as antihistamines, anticholinergics or antispasmodics. Thus, a consultation was re-quested from the Ear Nose Throat and Infectious Diseases (ENT) Department. ENT consultation revealed bilateral parotid gland swelling prominent on the right side while anterior rhinoscopy showed a normal bilateral space. The oral mucosa appeared normally moist and not inflamed. Autoscopic examina-tion showed that the bilateral external auditory canal was natural and bilateral tympanic membrane was intact. The systematic examination of the patient was normal and there was no fever. Infectious diseases consultation showed a parotid swelling and enduration with-out any infectious cause. Examinations revealed leukocytosis with a leukocyte value of 12.14 where nuetrophils accounted for $90 \%$, lympocytes for $7 \%$ and monocytes for $1.7 \%$.

Her blood amylase level was found to be above the normal level, namely $1595 \mathrm{U} / \mathrm{L}$. An infectious dis-eases consultation revealed that mumps-specific IgG antibody was posi-tive and IgM antibody was negative. No additional recommendations were made to increase the fluid support of the patient. Approixametly 30 hours after 131I administration, the parotid swelling of the patient disappeared. On the post-operative 8th day, 131I whole-body scintigraphy (WBS) was per-formed using large field-of-view, dual-head gamma camera (GCA7100-Toshiba) equipped with high energy parallel-hole collimator. WBS (whole-body scintigraphy) revealed increased iodine uptake at the right parotid area and an uptake focus compatible with the residual thyroid tissue at 
the neck region (Figure 1). Hemogram and serum amylase levels were measured again. After seven days, serum amylase was in normal values (95U/L). Also hemo-gram levels were normal. The patient was evaluated as having parotitis due to radioidine.

\section{DISCUSSION}

Radioiodine is concentrated and secreted into the saliva. Thus, salivary gland dysfunction is the most frequent complication of ablation therapy with radioiodine. Due to deep hypothyroid-ism, glomerular infiltration is decreased at the time of ablation therapy. For this reason, radioiodine is cleared from cir-culation much later and causes stasis of raidoiodine in the salivary glands. In the literature, the ratio of sialadenitis has been reported to be between $2.8 \%$ to $33 \%$ after RAI therapy [2]. Dose related damage to the salivary paren-cyhma results from the 131I irradiation [Jeong]. Transient sialadenitis is rare with smaller doses of radioactive idoined [3].

Salivary gland dysfunction is more common after repeated 131I ad-ministration [4]. Swelling and pain of salivary gland are the most common symptoms in early sialadenitis while xerostomia is the most prominent symptom in chromic sialadenitis after RAI therapy. An YS et al. [5] found the ratio of late-phase (mean 338 days) symptomatic sialadenitis as $10 \%$ after RAI therapy. Early sialadenitis occurs in a short time after RAI theraphy with swelling and pain symptoms and usual-ly subsides over a few days spontane-ously. Sialagogues, warm compress, steroids and cholinergic medications may be necessary. In recent studies, use of sialendoscopy has been reported in severe and refractory cases [6].

When compared to mucous cells, serous cells have a greater ability to trap idodide. Parotid gland involve-ment is observed more frequently as it contains more serous cells than mucous cells [7]. Moreover, high mucin secre-tion in the submandibular glands pro-tect these glands from exposure to radi-ation [5]. Interestingly, although its rea-son has not been fully explained yet, there are studies reporting that the right parotid gland is affected more [5]. Moreover, Jeong et al. [8] found that xerostomia is most frequently associat-ed with submandibular gland dysfunc-tion. Mandel et al reported that, in con-junction with the radiation sialadenitis, secondary complications may include xerostomia, taste alterations, infection, increases in caries, facial nerve in-volvement, stomatitis, candidiasis, and neoplasia [9]. Adequate hidration, sucking sweets or lemon juice advo-cates to reduce radiation damage to the salivary glands.

In a study conducted by Solans et al. [10] on 79 patients, $32.9 \%$ of the patients had subjective xerostomia and $25.3 \%$ had subjective xerophthalmia after radioiodine treatment. They found that xerostomia persisted to the second year of follow-up in $20.3 \%$ of the cases and was still present $>3 \mathrm{y}$ after the last does of radioiodine in $15.2 \%$ of cases while xerophthalmia persisted to the second year of followup in $17.7 \%$ of cases and was still present in the third year of follow-up in $13.9 \%$ of cases. They also reported that salivary gland dysfunction was relatively frequent after RAI therapy and this was transient in most cases but persisted for a long period in some patients.

In ablation therapy with 131I, Rosário et al. [11] found that hypera-mylasemia and symptoms of acute si-aloadenitis occured in $36.6 \%$ of the patients receiving recombinant-TSH (rhTSH) and $80 \%$ of the patients pre-pared by levothyroxine withdrawal. So, they reported a lower radiotoxicity with rhTSH.

Differentiated thyroid cancers are a relatively uncommon type of can-cer but are the most common cancers of the endocrine system, and their inci-dence has been rapidly increasing [12]. Differentiated thyroid cancers are treat-ed with high doses of 131I after total thyroidectomy. For this reason, history of RAI treatment should be given im-portance in patients applying either to emergency services or to ENT polyclin-ics with dry mouth.

In our patient, serum amylase level was measured as 1595 during the acute phase. Xerostomia is an important problem increasing morbidity of the patients. For this reason, it is important to prevent xerostamia by following serum amylase levels in symptomatic patients. Similar to bacterial parotitis and viral parotitisis, serum amylase level increase is observed in parotitis occuring due to ablation therapy with 131I. Before claiming that salivary gland enlargement developing after radioio-dine is a complication of radiation, one has to rule out other parotisis possibili-ties by clinical and laboratory findings. 


\section{REFERENCES}

1. Mazzaferri EL. The Diagnosis and imaging of Thyroid Cancer. In: Amdur JA, Mazzaferri EL, editors. Essentials of thyroid cancer management. Springer Science+Business Media, Inc. 2005; p: 39-120.

2. Almeida JP, Sanabria AE, Lima EN, Kowalski LP. Late side effects of radioactive iodine on salivary gland function in pa-tients with thyroid cancer. Head Neck 2011; 33: 686-90.

3. Lee HN, An JY, Lee KM, Kim EJ, Choi WS, Kim DY. Salivary gland dysfunction after radioactive iodine (I131) therapy in patients following total thyroid-ectomy: emphasis on radioactive iodine therapy dose. Clin Imaging 2015; S0899-707: 324-6.

4. Hyer S, Kong A, Pratt B, Harmer C. Salivary gland toxicity after radioiodine therapy for thy-roid cancer. Clin Oncol (R Coll Radiol) 2007; 19: 83-6.

5. An YS, Yoon JK, Lee SJ, Song HS, Yoon SH, Jo KS. Symptomatic lateonset sialadenitis after radioiodine therapy in thy-roid cancer. Ann Nucl Med 2013; 27: 386-91.

6. Prendes BL, Orloff LA, Eisele DW. Therapeutic sialendoscopy for the management of radioiodine sialadenitis. Arch Oto-laryngol Head Neck Surg 2012; 138: 15-9.

7. Mandel SJ, Mandel L. False-positive xerostomia following radioactive iodine treatment: case report. Oral Surg Oral Med Oral Pathol Oral Radiol Endod 2007; 103: e43-7.

8. Jeong SY, Kim HW, Lee SW, Ahn BC, Lee J. Salivary gland function 5 years after radioactive iodine ablation in patients with differentiated thyroid cancer: direct comparison of pre- and postablation scintigraphies and their relation to xerostomia symptoms. Thyroid 2013; 23: 609-16.

9. Mandel SJ, Mandel L. Radioac-tive iodine and the salivary glands. Thyroid 2003; 13: 265-71.

10. Solans R, Bosch JA, Galofré P, Porta
F, Roselló J, Selva-O'Callagan A, Vilardell M. Salivary and lacrimal gland dys-function (sicca syndrome) after radioiodine therapy. J Nucl Med 2001; 42: 738-43.

11. Rosário PW, Borges MA, Purisch S. Preparation with recombinant human thyroid-stimulating hormone for thyroid remnant ablation with $131 \mathrm{I}$ is associated with lowered radio-toxicity. J Nucl Med 2008; 49: 1776-82.

12. Pacini F, Schlumberger M, Dralle H, Elisei R, Smit J, Wiersinga W. European consensus for the management of pa-tients with differentiated thyroid carcinoma of the follicular epithelium. Eur J Endocrinol 2006; 154: 787-803. 